\title{
Minimum wage incidence: the case for Germany
}

\author{
Andreas Knabe* and Ronnie Schöb* \\ Freie Universität Berlin und CESifo
}

October 2008

\begin{abstract}
Using data from the 2006 wave of the German Socio-Economic Panel (GSOEP), this paper analyzes how a minimum wage affects employment, wage inequality, public expenditures, and aggregate income in the low-wage sector. It is shown that a statutory minimum wage of EUR 7.50 per hour would cost 840,000 low-paid jobs and increase the fiscal burden by about EUR 4 billion per year, while household income rises only by EUR 1.1 billion per year. Poor households, i.e. those eligible for Unemployment Benefits II, do not benefit from a minimum wage at all. Comparing the effects of a minimum wage with different types of wage subsidies that require the same additional public expenditures, the government can ensure more favorable employment - depending on the subsidies' incidence - and income effects. Wage subsidies also allow a more equal income distribution than statutory minimum wages. Combining a minimum wage with a wage subsidy, similar to the French minimum wage system, is extremely costly while such a policy is inferior to wage subsidies in all respects.
\end{abstract}

Keywords: $\quad$ minimum wage incidence, statutory minimum wage, welfare system, wage subsidies

JEL classification: $\quad \mathrm{H} 2, \mathrm{I} 3, \mathrm{~J} 3$

* School of Business \& Economics, Freie Universitaet Berlin, Boltzmannstr. 20,

D-14195 Berlin, Germany and CESifo, Munich.

Corresponding author: ronnie.schoeb@fu-berlin.de 


\section{Introduction}

Germany is one of the few OECD countries without statutory minimum wages. For a long time, there was no need for government intervention in the wage setting process since collective bargaining agreements between labor unions and employer federations ensured a stable wage distribution. While many other countries, most notably the United States, saw a sharp decline in the wage levels at the lower end of the wage distribution, the German wage structure remained essentially unchanged (Prasad 2004).

In the last decade, a number of factors have contributed to soften the cemented wage structure in Germany. First, the accession of Central and Eastern European countries into the EU common market brought low-wage competition to the German labor market. Second, the German government enacted several labor market reforms that aimed at increasing the willingness of the unemployed to take up low-paid jobs. Welfare levels were reduced, sanctions for unemployed persons who declined job offers were toughened, and various activation measures, ranging from training schemes and in-work benefits for low-wage workers to mandatory workfare programs, were introduced. These measures exerted downward wage pressure at the lower end of the wage distribution. Third, labor unions have lost a lot of their bargaining power. Between 1991 and 2007, the German trade union federation (DGB) lost almost half its members. These developments led to more wage dispersion and a growing low-wage segment in the German labor market (Brenke 2007, Gernandt and Pfeiffer 2007, Dustmann et al. 2008).

As long as unemployment rates were high, a larger low-wage sector was the bitter pill that the government was willing to swallow to bring people back into employment. Indeed, unemployment rates started to fall in 2005. Between August 2005 and August 2008, the German unemployment rate fell from 11.6 percent to 7.6 percent. For economists, the case is clear: lower wages, in particular at the lower end of the wage distribution, were necessary to bring unemployment down. Once unemployment rates start to fall, however, it becomes more difficult to convince wage setters that wages have to stay low. The latest economic upturn in Germany did not only lead to higher wage demands by unions, but also to the demand for a statutory minimum wage. The main objective of minimum-wage proponents (among them labor unions, the Social Democrats, and parts of the churches) is thereby to avoid in-work poverty. In their view, wages should be sufficiently high to secure a subsistence-level income. 
Minimum-wage proponents typically deny that such a policy would have negative employment effects.

Minimum wages also find support from parts of the government. After the reform to bring unemployed back into employment shows first successes, it becomes transparent that paying in-work benefits to low-wage workers implies that the government pays part of the wage bill of the growing low-wage sector. A minimum wage would ask the firms rather than the public to pay the bill. This argument is found, for example, in a leaflet of the Federal Ministry of Labor and Social Affairs, in which the ministry promotes statutory minimum wages. It argues that, in August 2007, more than 1.2 million low-wage workers had to receive in-work benefits through the welfare system to earn a subsistence-level income, which costs the government about EUR 1.5 billion per year (cf. Bundesministerium für Arbeit und Soziales 2008). While the extension of the low-wage sector was the initial intention of introducing in-work benefits in the first place, the Federal Ministry of Labor and Social Affairs now calls this an "erroneous trend" and argues in favor of minimum wages. The government's aim is to reduce its fiscal burden by shifting part of the cost of its welfare system to firms.

In this paper, we want to analyze whether the introduction of a minimum wage in Germany can fulfill the intentions of its proponents. In particular, we will examine

(a) how a minimum wage affects employment in the low-wage sector,

(b) whether minimum wages are able to raise aggregate incomes in the low-wage sector,

(c) whether minimum wages can reduce overall wage inequality, and

(d) whether the government can expect to reduce its fiscal burden by introducing minimum wages.

To simulate these effects, we use data from the 2006 wave of the German Socio-Economic Panel (GSOEP), a representative longitudinal study of private households in Germany.

Some of these questions have already been examined in other studies. Ragnitz and Thum (2007) estimate the employment effects of introducing a minimum wage in Germany. They find that the introduction of a minimum wage of EUR 7.50 per hour would cost about 1.1 million jobs. Müller and Steiner (2008a,b) look at the potential employment and income effects. They estimate that about 260,000 jobs would be lost if a minimum wage at 7.50 Euro would be introduced. Moreover, they conclude that minimum wages would be ineffective in reducing poverty even if they did not have any negative employment effects. Bachmann et al. (2008) analyze the employment and fiscal effects. According to their study, a minimum wage 
of EUR 7.50 would lead to a loss of 1.2 million jobs. Contrary to its hopes, the government would not be able to reduce its expenditures. Instead, the public budget would be burdened by additional EUR 9 billion per year, mainly due to expenditures on unemployment and welfare benefits for those workers that lose their jobs.

Our paper differs from existing studies by analyzing the employment, income, and fiscal effects of a minimum wage in one consistent framework. Since minimum wages are typically understood as a means to achieve the end of securing a minimum income of the working poor (see Kleinhenz and Bauernschuster 2008), we compare our findings with results for alternative policy measures that also aim at improving the employment and income prospects at the bottom end of the wage distribution. In particular, we compare the effects of minimum wages with wage subsidies that either stimulate employment (if the incidence is on employers) or raise wages directly (if the incidence is on employees). Finally, we ask whether experiences from other countries can be transferred to Germany to alleviate the negative employment effects of minimum wages. Here we consider the French approach to neutralize a statutory minimum wage with an accompanying wage subsidy to employers (see Kramarz and Phillipon, 2001, and Laroque and Salanié, 2002). We are interested to learn in how far such a policy may be a reasonable policy measure to raise the incomes of the poor without endangering their employment prospects. We evaluate these alternative policies in the same reference scenario as the minimum wage.

The paper is structured as follows. In Section 2, we describe our data. Section 3 contains our findings concerning the employment, income, and fiscal effects of minimum wages. In Sections 4, we compare these effects with general wage subsidies for different subsidy incidences. In Section 5, we analyze whether combining minimum wages and wage subsidies is superior to employing only one of the two instruments. Section 6 contains a discussion of our results.

\section{Data description}

To identify the size and structure of the labor market segment potentially affected by minimum wages, we make use of the German Socio-Economic Panel (GSOEP) for the year 2006. The GSOEP is a representative longitudinal study of private households in Germany. The questioning population of the SOEP is private households and their members who reach 
the age of 17.1 The same data basis was used by Bachmann et al. (2008) and Müller and Steiner $(2008 \mathrm{a}, \mathrm{b})$ to study minimum wage effects. Since minimum wages will not be introduced in Germany before the next federal election at the end of 2009, we extrapolate wages to the beginning of 2010 based on realized growth rates for 2006 and 2007 as well as expected growth rates for 2008 and $2009 .^{2}$

In its 2006 wave, the GSOEP contains 29,022 individual observations. The GSOEP'S sampling weights imply that these observations are representative of about 82 million persons living in Germany. For our analysis, we restrict our attention to individuals in dependent employment relationships. In particular, we include all persons who are full-time or part-time employed or who work in a so-called "minijob" (jobs paid at less than EUR 400 per month that are partially exempted from social security contributions and taxes). We thus exclude all individuals who are out of the labor force, self-employed, fulfilling their mandatory civil or military service or are in vocational training, or who work in publicly subsidized employment programs or in special workshops for disabled persons.

The GSOEP does not contain direct information on hourly wages. Instead, respondents are asked in a number of separate questions about their gross labor income in the month preceding the interview and about their hours of work. Respondents can state their contractual weekly working hours, the number of overtime hours (paid and unpaid), and/or the number of hours actually worked. We follow Müller and Steiner (2008a,b) in calculating a person's hourly wage by dividing his gross income by the number of paid hours (contracted plus paid overtime hours). Different to Müller and Steiner (2008a,b) who exclude regular jobs with imputed hourly wages below EUR 3, we assume an average hourly wage of EUR 2.75 for these workers to account for measurement errors in the hours and wage data.

Not all GSOEP respondents give all the necessary information on their wages and working hours. To correct for the missing observations, we assume that the remaining observations in each subgroup (full-time, part-time, and minijobs) are also representative for the observations lost in each group. We can then rescale the sampling weights to readjust the number of individuals represented by our sample to correspond to their actual number in Germany. Our sample contains observations representing 16.8 million of the 23.5 million full-

\footnotetext{
${ }^{1}$ For a detailed description of the GSOEP, see Wagner et al. (2007).

2 Most interviews in the SOEP take place in the first quarter of the year. The realized growth rate between the first quarters of 2006 and 2007 was 0.6\%. Between 2007 and 2008, it was 2.2\% (Bundesbank 2008). Expected wage growth rates for 2008-2009 and 2009-2010 are 2.2\% and 2.6\%, respectively (Projektgruppe Gemeinschaftsdiagnose 2008).
} 
time employees, 4.4 million of the 4.8 million part-time employees, and 1.4 million of the 4.9 million persons with a minijob (Statistisches Bundesamt 2006, 2007). Therefore, we multiply the sampling weights of full-time employees by 1.395 , of part-time employees by 1.098 , and of persons with a minijob by $3.359 .{ }^{3}$

A substantial share of low-wage employment consists of students and pensioners that try to earn some money "at the side". These people have to be analyzed separately from "regular" low-wage workers because they cannot receive supplementary welfare benefits and are not covered by unemployment insurance if they lose their jobs. We classify as students all people attending a general school (in the regular 12-year-school-system) or an institution of higher education (college or university). Pensioners are people who receive an old-age pension and are at least 60 years old.

Table 2.1: Cumulative frequencies in the low wage segment

\begin{tabular}{c|ccccc|c}
\hline \hline & $\begin{array}{c}\text { Full-time } \\
\text { employees }\end{array}$ & $\begin{array}{c}\text { Part-time } \\
\text { employees }\end{array}$ & Minijobs & Pensioners & Students & Total \\
& $(1)$ & $(2)$ & $(3)$ & $(4)$ & $(5)$ & $(6)$ \\
\hline \multirow{2}{*}{$<5.00$} & 158,529 & 13,093 & $1,127,358$ & 67,535 & 125,253 & $1,491,768$ \\
& $(0.7 \%)$ & $(0.3 \%)$ & $(28.7 \%)$ & $(15.4 \%)$ & $(22.3 \%)$ & $(4.5 \%)$ \\
$<6.00$ & 415,042 & 71,524 & $1,488,590$ & 123,848 & 173,788 & $2,272,793$ \\
& $(1.8 \%)$ & $(1.5 \%)$ & $(37.9 \%)$ & $(28.2 \%)$ & $(30.9 \%)$ & $(6.9 \%)$ \\
& $1,068,887$ & 335,915 & $2,325,187$ & 200,178 & 279,010 & $4,209,177$ \\
$(1.50$ & $(4.6 \%)$ & $(7.1 \%)$ & $(59.2 \%)$ & $(45.6 \%)$ & $(49.6 \%)$ & $(12.8 \%)$ \\
\hline \multirow{2}{*}{ Total } & $23,191,183$ & $4,750,328$ & $3,926,480$ & 439,308 & 562,440 & $32,869,740$ \\
\hline \hline
\end{tabular}

Source: GSOEP, wave 2006, own calculations.

Note: The values in parentheses are cumulative employment shares for the subgroup in each column.

Table 2.1 (Column 6) and the left panel of Figure 2.1 display the distribution of hourly wages that we obtain from our sample for the entire working population. For the low-wage sector, we find that 1.5 million people (4.5\% of all employees) work for less than EUR 5 per hour, 2.3 million people (6.9\%) for less than EUR 6 per hour, and 4.2 million people $(12.8 \%)$ for less than EUR 7.50 per hour. The median hourly wage is about EUR 14.50, and only $10 \%$ of all employees are able to earn hourly wages above EUR 26.50 .

\footnotetext{
3 The large loss of observations for persons with a minijob occurs because almost half of the 987 respondents with a minijob (representing 3.1 million persons) did not state a number of contracted working hours.
} 
Figure 2.1: Cumulative distribution of hourly wages
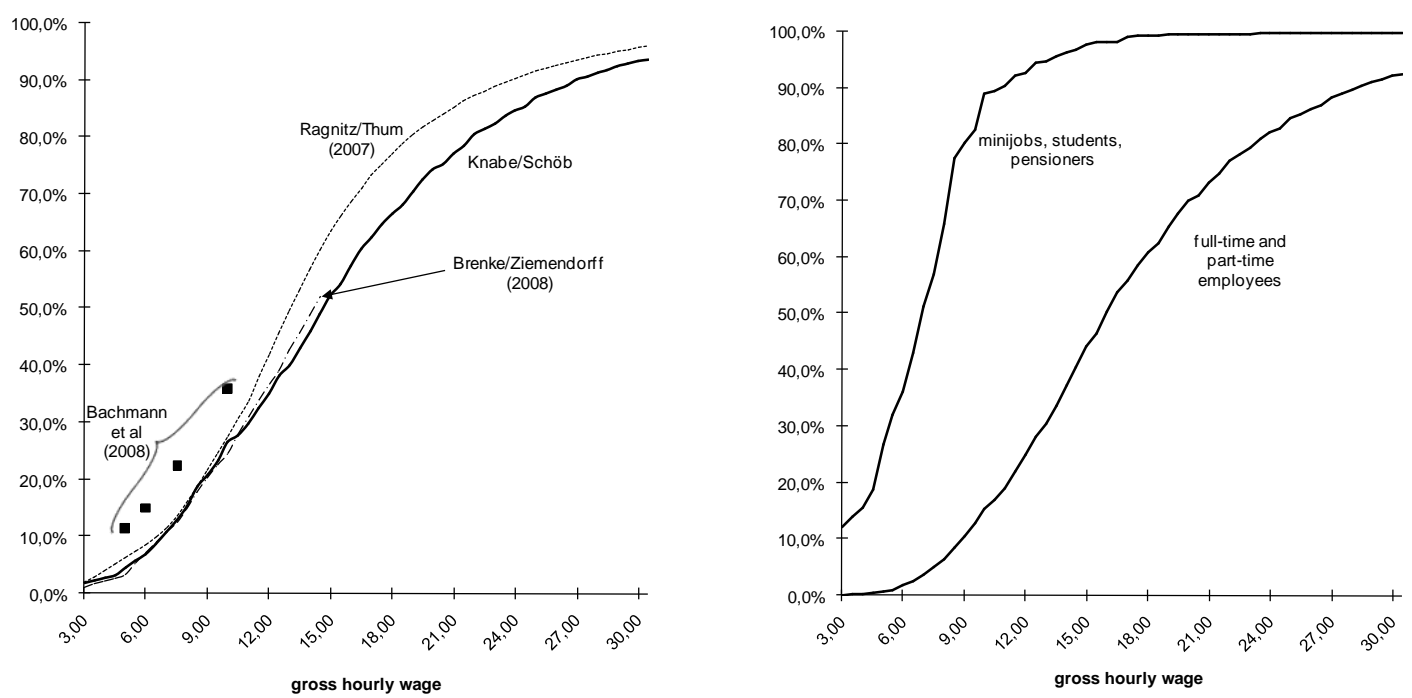

Source: GSOEP, Brenke and Ziemendorff (2008), Ragnitz and Thum (2007), Bachmann et al. (2008), own calculations.

To check the validity of our sample, we compare our wage distribution to the one obtained by Brenke and Ziemendorff (2008), who also use the GSOEP wave 2006, and Ragnitz and Thum (2007), who use the German Federal Statistical Office's survey on the salary and wage structure in the manufacturing and service sectors for 2001. Ragnitz and Thum (2007) obtain that $6.4 \%, 8.6 \%$, and $13.5 \%$ of all employees work for less than EUR 5, 6, and 7.50 per hour, respectively. Since we take the growth of the wage rates into account, these figures are slightly larger than our figures reported in Table 2.2.

The RWI study (Bachmann et al. 2008) obtains substantially larger employment shares in the low-wage segment. According to their results, the shares of employees earning hourly wages below EUR 5, 6, and 7.50 Euro are $11.3 \%, 15.1 \%$, and $22.3 \%$, respectively. There are two reasons for the large discrepancies between the RWI study and our study. First, the RWI calculates hourly wages by dividing gross wages by the larger of either contracted or actually worked hours. Actually worked hours include unpaid hours that, by definition, do not affect a person's earnings. The RWI thus calculates effective hourly wages, which are systematically smaller than contracted hourly wages. Any minimum wage legislation, however, can only refer to contracted wages, so that the RWI method overestimates the share of the workforce affected by minimum wages. The second reason why the RWI study obtains larger shares is that they include employees who are in vocational training and people who 
work in public job creation schemes. Both groups do not receive regular wages, but are paid either a small apprenticeship remuneration or receive only an allowance for special expenses associated with participating in a job creation scheme. In any case, both groups would not be covered by minimum wage legislations. Including them thus overestimates the share of the workforce affected by a minimum wage.

Low wages are much more prevalent among "irregular" labor market groups. To illustrate this point, Table 2.1 and the right panel of Figure 2.1 show separate distributions for regular full-time or part-time workers on the one hand, and irregular workers, i.e. persons with a minijob, students, and pensioners, on the other. As can clearly be seen, the share of full-time and part-time workers working at low wages is much smaller than the share of irregular workers in the same wage segment. While only $5.0 \%$ of all full-time and part-time employees earn less than EUR 7.50 per hour, $57 \%$ of persons with a minijob, students, and pensioners can be found in that segment. Only $10 \%$ of the latter group earns more than EUR 10 per hour. Comparing low-wage employment across groups shows that $87 \%(42 \%)$ of all employees working for less than EUR 5 (EUR 7.50) per hour belong to irregular labor market groups, while their share in the total workforce is only $15 \%$. These data already illustrate that the effects of a minimum wage will be felt much stronger among irregular labor market groups than among regular full-time and part-time employees. 
Table 2.2: Share of employees in eastern and western Germany affected by a minimum wage

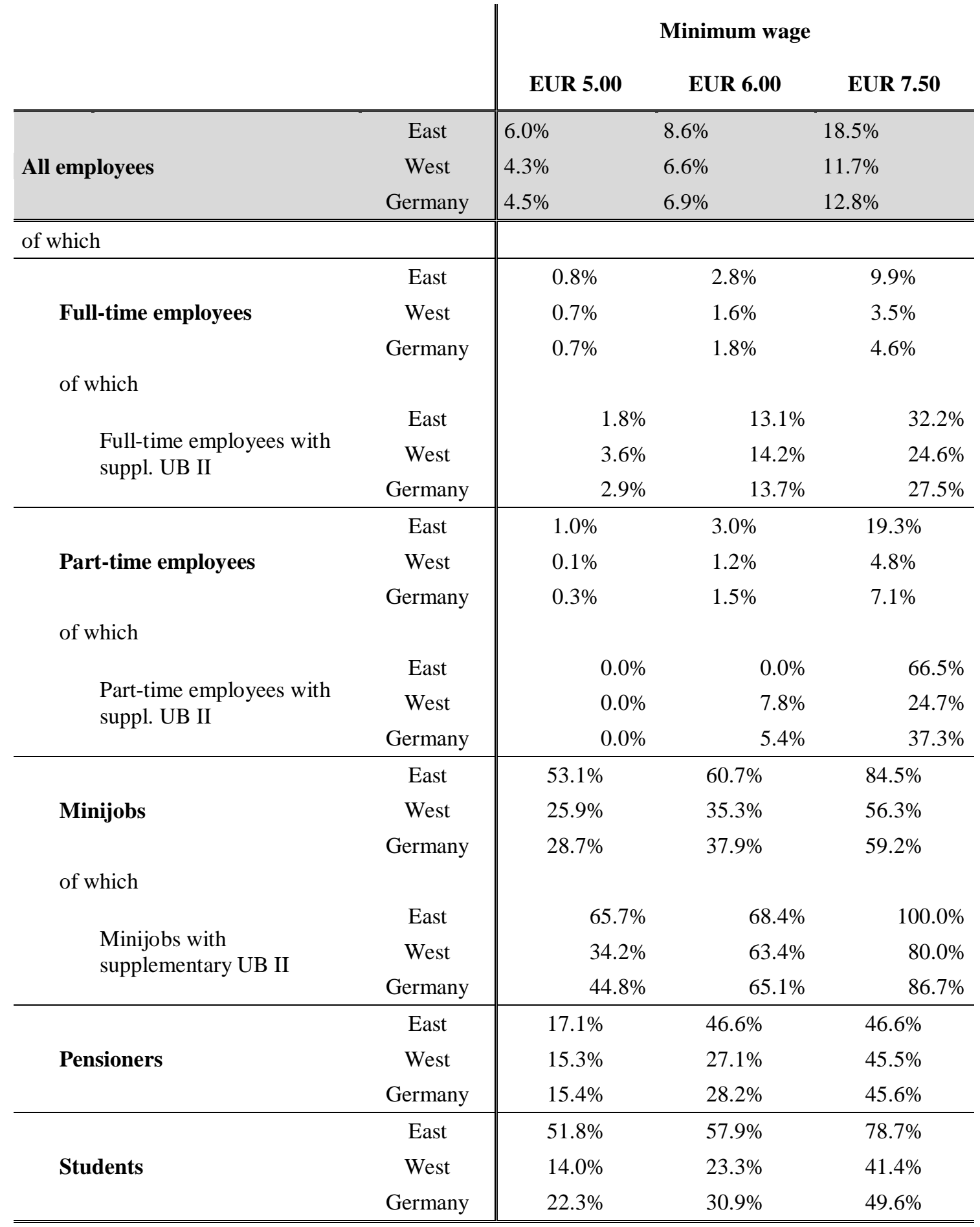

Source: GSOEP, own calculations. The results for Germany correspond to the figures presented in Table 2.1.

There are huge regional differences when we compare eastern and western Germany. Table 2.2 regionally disaggregates the figures presented in Table 2.1 and shows the shares of the workforce of different types of employees that would be affected by introducing a minimum 
wage for both eastern and western Germany. The shares of workers affected by a minimum wage of EUR 5, 6, and 7.50 Euro in the East are $6.0 \%, 8.6 \%$ and $18.5 \%$, whereas the figures for the West are substantially lower with $4.3 \%, 6.6 \%$ and $11.7 \%$. Accordingly, the minimum wage can be expected to have much higher adverse effects in the East than in the West.

In Germany, low-wage earners can receive means-tested welfare benefits, so-called supplementary unemployment benefits II (Arbeitslosengeld II, in short UB II), on top of their wage incomes. ${ }^{4}$ The means test requires that their total household income would be below the socio-cultural subsistence level if the household did not receive supplementary benefits. In our analysis, we can distinguish between recipients of UB II and other employees in the lowwage sector, which is important when we calculate fiscal and distributional effects of minimum wages. Since UB II is a benefit granted to the entire household and not to individual persons in each household, we identify all persons in the GSOEP as UB II recipients who live in a household in which some person receives UB II. Table 2.2 presents the figures for these subgroups. As one would expect, the share of low-wage workers is larger among the subgroup of supplementary UB II recipients than among all employees. $27.5 \%$ (37.3\%) of all full-time (part-time) employed UB II recipients receive wages less than EUR 7.50 per hour. Among persons with a minijob who obtain supplementary UB II, the share of workers earning less than EUR 7.50 per hour is even $86.7 \%$. Students and pensioners are not eligible for UB II.

\section{Effects of a statutory minimum wage}

The empirical literature on the employment effects of minimum wages does not paint a clear picture. Early studies, which estimate economy-wide labor demand equations and then predict the separate effect of a rise in the wage of low-paid workers on the demand for all factors of production, generally arrive at negative employment effects (for an overview, see Brown 1999). A different method is the quasi-experimental approach where one examines situations in which the minimum wage is raised in one region, but stays constant in another, otherwise comparable region. The effect of the minimum wage is then determined by the differential employment growth in the two regions. This approach was first applied by Card and Krueger (1994) who find that the increase in the minimum wage in New Jersey did not have a negative effect, and might even have had a positive effect on employment compared to Pennsylvania,

\footnotetext{
${ }^{4}$ We model the regulations according to the German Social Code II (SGB II) as of September 2008.
} 
where the minimum wage stayed constant. ${ }^{5}$ Following the approach by Card and Krueger (1994), a quasi-experimental study was recently conducted by König and Möller (2007) for the German construction industry. They find that the minimum wage had a positive, although only weakly significant effect on employment in this industry in West Germany. For East Germany, they find that the minimum wage resulted in job losses. One weakness of the study by König and Möller (2007) appears to be that the dataset employed includes only German nationals. According to Meier and Munz (2008), this ignores the main target group of the minimum wage - foreign workers. Employment in the German construction sector comprised a large share of low-wage workers from Central and Eastern European countries. The introduction of minimum wages thus mainly raised the cost of employing foreign workers and could potentially have led to the substitution of German for foreign workers. Restricting the analysis to German nationals thus systematically underestimates the adverse employment impact of minimum wages.

Even though claims that minimum wages either have positive, negative, or no employment effects at all can find supporting evidence in several empirical studies, metastudies of the empirical literature paint a rather clear picture. In a recent survey, Neumark and Wascher (2007) review empirical studies on the employment effects of minimum wages conducted after Card and Krueger (1994) stimulated the "new minimum wage research". While a "consensus view" clearly does not exist, the vast majority of studies points to negative employment effects of minimum wages. Of the 102 studies surveyed by Neumark and Wascher (2007), two-thirds indicate that minimum wages have a negative (although not always significant) effect on employment, while only eight studies arrive at the opposite result. Positive employment effects are typically found by short panel data studies or case studies of the effects of a state-specific change in the minimum wage on a particular industry, while longer panel studies and studies that focus on broader groups generally find negative employment effects. In sum, Neumark and Wascher (2007) conclude that the literature supports the conventional view that minimum wages have negative employment effects and that the labor market can be reasonably approximated by the neoclassical model.

\footnotetext{
5 This result has been questioned by Neumark and Wascher (2000). They also look at the effects of the minimum wage on employment in New Jersey's fast-food industry but use payroll data instead of personal statements by managers. Contrary to Card and Krueger (1994), Neumark and Wascher (2000) find that employment declined in New Jersey relative to Pennsylvania.
} 
We apply such a standard model of a neoclassical labor market where firms employ workers as long as their marginal value product is at least as high as their wage cost. If wage increases are not covered by productivity increases, they will have negative employment effects because firms will lay off all workers whose marginal value product does not suffice to cover the higher labor cost. ${ }^{6}$ To estimate how large the employment effects would be at different minimum wage levels, we follow the methodology of Ragnitz and Thum (2007). We assume that there is a labor demand function $L(w)=w^{\eta}$, where $w$ is the gross labor cost the employer has to pay for each worker, and $\eta$ is the (constant) wage elasticity of labor demand. The employment effect of a wage increase from $w<w^{\min }$ to a new minimum wage $w^{\min }$ can then be calculated by

$$
\text { employment reduction (in } \%)=\left(\frac{w^{\min }}{w}\right)^{-\eta}-1
$$

Empirical estimates of the labor demand elasticity in the German low-wage sector range between -0.6 and -2 (see Sinn et al. 2006, 145, for an overview). We follow Ragnitz and Thum (2007) by assuming a rather cautious labor demand elasticity of -0.75 .

Our simple simulation assumes away from any complementarity and substitutability relationship of the different types of work. For the purpose of our analysis, this may be justified for two reasons. First, we know very little about how output reactions affect the respective labor demand elasticity. If we assume, as Müller and Steiner (2008b) do, a single output good, the output reaction plays a very minor role since the factor income share of those being affected by the minimum wage is rather small. If, by contrast, we assume that workers in each wage bracket produce a separate good, we need to know the output substitution elasticities. Looking at non-marginal changes in the lower income distribution thus would make any assumption about substitution elasticities - even if based on empirical estimates highly speculative. Second, we also know very little about the incidence of a statutory wage rise. If better paid workers face relatively flexible wages, most of the substitution effect will be evaporated by wage reactions that counteract potential employment effects in higher wage brackets. In this case, it is justified to restrict our attention to the employment effects in the low-wage segment.

\footnotetext{
6 The effects of minimum wages in a standard neoclassical labor market are comprehensively discussed by Brown (1999).
} 


\subsection{Minimum wage incidence}

Minimum wages have distributional as well as allocative consequences. The winners and losers of minimum wages can be identified by a simple diagrammatic analysis. Figure 3.1 shows a standard neoclassical labor market with a labor demand curve $L(w)$. We do not model labor supply explicitly but assume an initial wage of $w^{0}$ that leads to an initial employment level of $L^{0}$. Firms' profits are given by the area ABC, and the wage sum of all workers is given by the CBDE. If a minimum wage $w^{\min }>w^{0}$ is introduced, firms will reduce their labor demand to $L^{\mathrm{min}}$. Obviously, firms lose from the minimum wage because their profits fall by GFBC. Workers are exposed to two opposing effects. On the one hand, the minimum wage raises the incomes of the $L^{\text {min }}$ workers that keep their jobs by the area GFHC. On the other hand, $L^{0}-L^{\text {min }}$ workers lose their jobs and suffer from an income reduction of HBDI. The total effect on workers' incomes is ambiguous and depends on the relative size of GFHC compared to HBDI. In the case depicted in Figure 3.1, the minimum wage redistributes income from firms and those workers that become unemployed to the workers that remain in employment.

The incidence is quite different if the government has already implemented a basic welfare system before the minimum wage is introduced. Welfare programs typically allow their recipients to keep a certain fraction of any wage income they earn to give them an incentive to look for a job. In Germany, UB II recipients can keep income less than EUR 100 per month without suffering from benefit deductions. The government deducts $80 \%$ from gross wages between EUR 100 and EUR 800 per month, and $90 \%$ from gross wages between EUR 800 and EUR 1,200 per month (EUR 1,500 per month if there are children in the household). Income above this threshold is completely deducted from welfare benefits. The gross UB II entitlement minus the deductions from wage income is then paid out as supplementary welfare benefits. The high benefit reduction rates imply that higher wages will increase a household's disposable income by only very little. This will reduce any positive impact of minimum wages on the incomes of private households. 
Figure 3.1: Minimum wage incidence

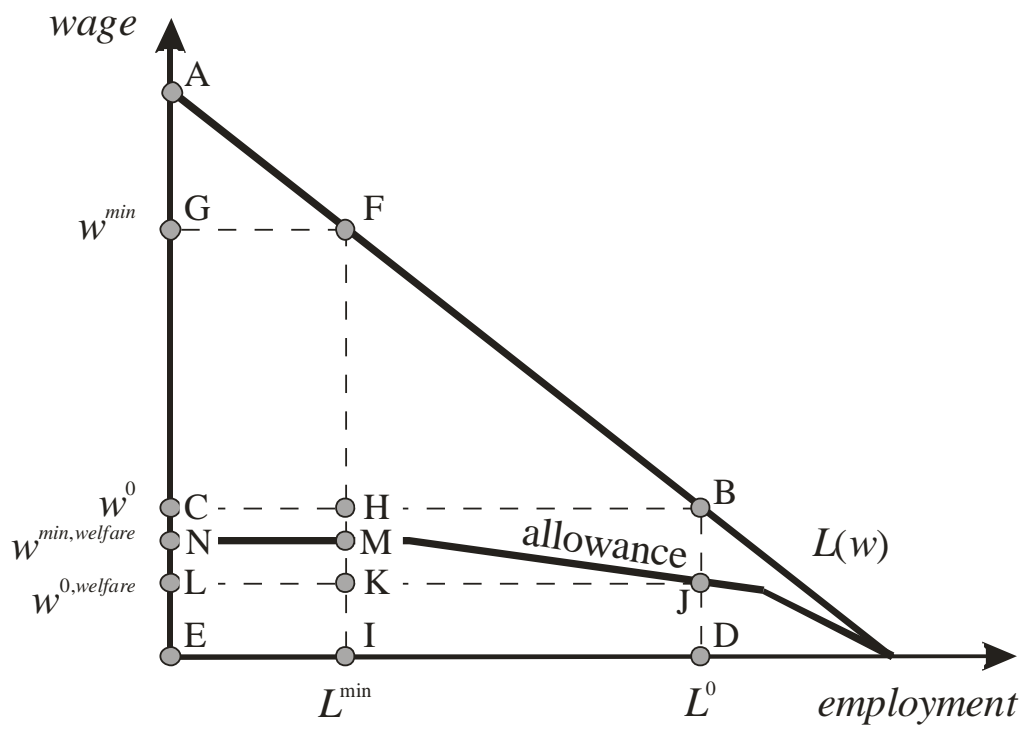

Figure 3.1 also illustrates this case. We add a schematic "allowance"-line to the graph that shows how much of the wage the firm pays can be kept by a welfare recipient after any applicable deductions have been made. From the initial gross wage $w^{0}$, a welfare recipient could keep only $w^{0 \text {,welfare }}$ in addition to his welfare benefits after deductions are subtracted. The difference $w^{0}-w^{0 \text {,welfare }}$ is received by the government. Examining the total market, firms' profit is still $\mathrm{ABC}$, but household net income from work is only LJDE (in addition to the basis income the household would receive if unemployed). The area CBJL enters the public budget.

If a minimum wage is introduced at $w^{\min }$, labor demand falls to $L^{\min }$ and firms' profits are reduced by GFBC as in the case without welfare benefits. The welfare benefits, however, affect the distribution of gains between the government and the affected households. The minimum wage raises the household's income allowance from $w^{0 \text {,welfare }}$ to $w^{\text {min,welfare }}$. In the aggregate, this means that those workers who keep their jobs gain NMKL, and the workers that lose their jobs have to give up their allowance KJDI. Since higher incomes are deducted at higher benefit reduction rates, the increase in income among the further employed workers is rather small compared to the income loss of the unemployed households. Hence, the existence of supplementary welfare benefits makes it more likely that the total net wage sum among all workers falls when minimum wages are introduced. The government also loses the income it had so far deducted from the workers who lose their job after the minimum wage is implemented. In the figure, this corresponds to the area HBJK. At the same time, it can deduct more income (GFHC) from workers who keep their jobs but also it has to grant them higher 
allowances (NMKL). The total effect on the public budget is thus GFHC-NMKL-HBJK. It is ambiguous whether the government gains or loses revenues by introducing a minimum wage.

\subsection{Employment effects}

How many of those workers who are affected directly by a statutory minimum wage will lose their jobs? With an iso-elastic labor demand elasticity of -0.75 for each wage bracket, the introduction of a statutory hourly minimum wage of EUR 7.50 in 2010 would lead to a total loss of more than 842,000 jobs ( $2.6 \%$ of the workforce). Almost one fourth of the job losses would occur in eastern Germany. This would imply a reduction of the East German work force by $3.8 \%$. The figures for a minimum wage of EUR 7.50 are about $20 \%$ smaller than the figures calculated by Ragnitz and Thum (2007). The differences are even larger for the other two minimum wage levels under investigation. This is due to three effects. First, different to Ragnitz and Thum we adjust the hourly wages by taking into account the wage growth from 2006 to 2010, which amounts to almost $8 \%$. Second, the GSOEP data suggest a somehow lower density in the lower wage brackets below EUR 5.00 (see Figure 2.1). Third, we have assumed for all employees who reported a gross wage below EUR 3.00 an average wage of EUR 2.75 to correct for substantial statistical uncertainty and measurement errors in this wage interval. ${ }^{7}$

The top lines of Table 3.1 present the main results with respect to the aggregate employment effects. Aggregate figures, however, may paint a biased picture. For instance, many supporters of a statutory minimum wage would hardly moan about losses of so-called minijobs. They are mainly arguing that a statutory minimum wage is necessary to avoid inwork poverty when working full-time. Therefore, we also present the disentangled employment effects for the different groups in the two regions. Thereby, we assume that all jobs are equally endangered from wage increases.

\footnotetext{
${ }^{7}$ If we excluded all observations below EUR 3.00 completely (as was done by Müller and Steiner (2008b)), we would obtain substantially lower estimates. For instance, the total employment loss from a minimum wage of EUR 7.50 would be below 534,000 lay-offs.
} 
Table 3.1: Employment effects for different job types

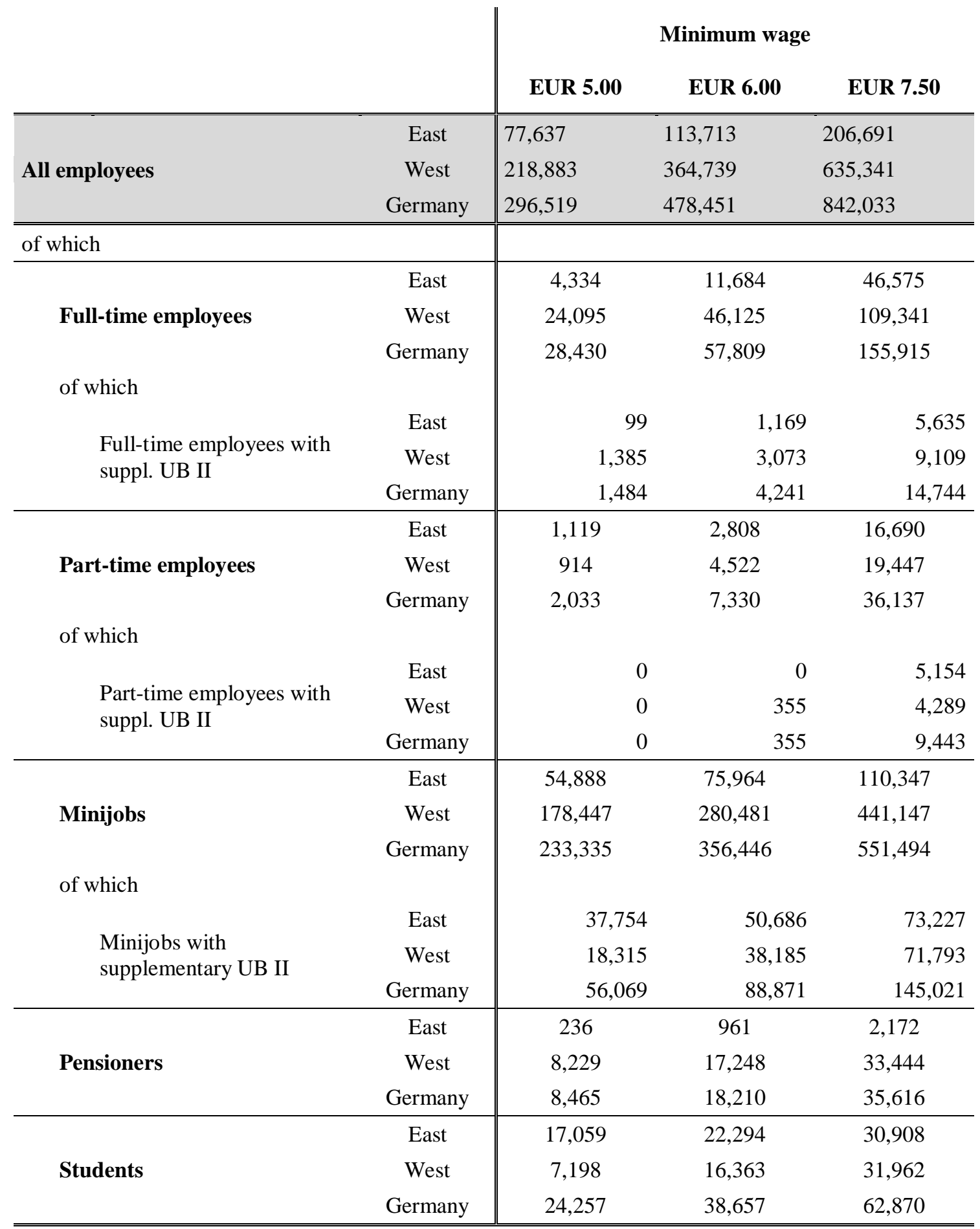

Source: GSOEP, own calculations.

Table 3.1 shows that a statutory minimum wage of EUR 5.00 would only affect about 28,000 full-time workers, i.e. $0.1 \%$ of all full-time employees. The job losses would increase to 156,000 full-time employees, i.e. still less than $0.7 \%$ of all full-time employees, if a statutory minimum wage of EUR 7.50 would be introduced. About $90 \%$ of the job losses resulting 
from a EUR 5.00 minimum wage accrue to employees with a minijob and to pensioners and students. For a minimum wage of EUR 7.50, this figure would be $77 \%$. About 15,000 UB II recipients who work full-time would lose their job due to a EUR 7.50 minimum wage and about 145,000 UB II recipients who have a minijob.

\subsection{Income effects}

The income effects differ widely between the different groups. This is mainly due to the asymmetry with which the German system of basic income support treats income losses and gains (see Figure 3.1). These differences in the income effects of introducing a statutory minimum wage are best illustrated by looking at a hypothetical single employee who currently works 160 hours per month for a gross hourly wage of EUR 5.00 and will now face a wage increase to EUR 7.50.

1. If the employee remains in employment, her gross wage income would rise from EUR 800 per month by $50 \%$ to EUR 1,200 per month. If she does not depend on additional public transfers, her net wage income would rise by EUR 261 from EUR 644 to EUR 905 per month. This is a $32 \%$ increase in net income.

2. If the employee has neither non-labor income nor wealth, she is entitled to supplementary UB II. The basic income when unemployed is EUR 666 per month. When she works 160 hours per month and earns an additional labor income of EUR 800, she is allowed to keep EUR 240 of her gross wage income so that her current net income is already EUR 906. If her gross hourly wage rises to EUR 7.50, she would earn 1,200 Euro but still be entitled to supplementary UB II. In the income interval from EUR 800 to EUR 1,200 applies a transfer deduction rate of 90 percent so that her monthly net income would merely rise by EUR 40 to EUR 946: a 50 percent increase in the gross wage results in a mere 4.4 percent increase in the net income.

3. If an employee who is not entitled to UB II becomes unemployed after the statutory minimum wage has been introduced, her net income would fall from EUR 644 to the level of unemployment benefits I (Arbeitslosengeld I, UB I). UB I replaces $60 \%$ of a person's net income, in our case EUR 386.

4. If the employee receives supplementary UB II and becomes unemployed, she would lose the EUR 240 she was allowed to keep from the initial gross wage income. 
By assuming that all types of workers face the same risk of being laid off, we can calculate the aggregate income gains for these four different groups in each wage bracket. In the same way we proceed with minijob employees. Pensioners and students are not entitled to supplementary benefit payments so that we only distinguish between those remaining in employment and those losing their jobs.

The second column in Table 3.2 reports the additional annual net income for all households directly affected by the introduction of a statutory minimum wage of EUR 7.50.

Table 3.2: Income and fiscal effects of a statutory minimum wage of EUR 7.50 per hour

\begin{tabular}{r|r|r|r|r|r|r|r} 
& $\begin{array}{c}\text { Additional } \\
\text { income in } \\
\text { mill. euro/a }\end{array}$ & $\begin{array}{c}\text { Share of } \\
\text { additional } \\
\text { income }\end{array}$ & $\begin{array}{c}\text { Share of } \\
\text { UB II } \\
\text { recipients }\end{array}$ & $\begin{array}{c}\text { Additional } \\
\text { income for } \\
\text { UB II } \\
\text { recipients } \\
\text { in mill. } \\
\text { euro/a }\end{array}$ & $\begin{array}{c}\text { Fiscal cost } \\
\text { in mill. } \\
\text { euro/a }\end{array}$ & $\begin{array}{c}\text { Share of } \\
\text { total fiscal } \\
\text { cost }\end{array}$ & $\begin{array}{c}\text { Implicit } \\
\text { net } \\
\text { transfer } \\
\text { rate }\end{array}$ \\
\hline All & 1,156 & $100.0 \%$ & $14.9 \%$ & -73 & $-4,011$ & $100.0 \%$ & $28.8 \%$ \\
Full-time & 817 & $70.7 \%$ & $7.6 \%$ & 1 & $-1,974$ & $49.2 \%$ & $41.4 \%$ \\
Part-time & 132 & $11.4 \%$ & $21.0 \%$ & -5 & -280 & $7.0 \%$ & $47.0 \%$ \\
Minijobs & 142 & $12.3 \%$ & $21.4 \%$ & -69 & $-1,522$ & $37.9 \%$ & $9.4 \%$ \\
Pensioners & 18 & $1.5 \%$ & $0.0 \%$ & --- & -98 & $2.4 \%$ & $18.1 \%$ \\
Students & 47 & $4.0 \%$ & $0.0 \%$ & --- & -137 & $3.4 \%$ & $33.9 \%$
\end{tabular}

Source: own calculations.

Total income of the households rises by EUR 1.2 million per year. The largest income gain accrues to full time employees who receive $71 \%$ of the additional household income. The picture changes when we focus on those employees in need, i.e. those who receive supplementary UB II. Those who remain in employment enjoy a wage increase that is, however, very low because of the high transfer reduction rates. Those who lose their jobs will face a significantly higher loss in income.

This may be illustrated with our example from above. At the assumed labor demand elasticity of -0.75 , a rise from an hourly wage of EUR 5.00 to a minimum wage of EUR 7.50 would cost 26 out of 100 employees their jobs. Their net income would fall from initially EUR 906 to the basic income level of EUR 666. The remaining 74 employees each have an additional income of EUR 40 so that the total available income of all 100 employees, who are eligible for UB II, is reduced by 3.6 percent. Summing up over all wage brackets, UB II households will lose almost EUR 73 million per year in the aggregate. The main beneficiaries 
are thus those low-paid employees who are not entitled to supplementary UB II. ${ }^{8}$ Apparently, the minimum wage - even at the level suggested by trade unions and left-wing politicians can hardly be seen as an appropriate instrument to fight in-work poverty when working fulltime.

The expression "working poor" is associated with income below a 'at risk of poverty"threshold that is at $60 \%$ of the median income according to a EU definition (European Commission 2006). In Germany, this threshold is at a monthly net income of EUR 781 per month for a single person and between EUR 1,640 and EUR 1,953 per month for a family of four, depending on the children's age. The current German system of supplementary income support for those households in need already ensures that those working - even when they only have a minijob - are already above this threshold, while those people who would lose their jobs due to the introduction of a statutory minimum wage would be thrown below this threshold. To put it bluntly: without successfully fighting in-work poverty, a statutory minimum wage runs the risk of making the group of "unemployed poor" even larger. A statutory minimum wage puts almost 170,000 employees with supplementary UB II benefits plus their family members into the risk of poverty, but fails to lift anyone in need out of it.

\subsection{Inequality}

Within each wage bracket as well as within the group of all households being affected by the introduction of the statutory minimum wage, inequality rises. This is intuitively clear as the incomes become more dispersed. While people that remain employed earn more, other people who lose their jobs earn less. To verify the intuition, we calculate the change in the Atkinson index for full-time employees. Irrespectively of what assumptions we make about the income of those not eligible for UB II, the Atkinson index is rising for all groups. ${ }^{9}$ The inequality effects are not as clear when we extend our analysis from the affected wage brackets to the entire labor force, including also the initially unemployed and people earning more than EUR 7.50 per hour. The minimum wage lifts up the wages of those that remain in employment. Since these people were located at the bottom end of the income distribution, this reduces income inequality. At the same time, those people that lose their jobs move even further down the income distribution, thereby increasing income inequality. It turns out that when we

\footnotetext{
${ }^{8}$ Among these are also people who decided not to apply for UB II although they are eligible to. According to Becker (2007), this group may be as large as 900,000 persons.

${ }^{9}$ The Atkinson index is calculated for an inequality aversion of $\varepsilon=1$, which yields a logarithmic utility function.
} 
consider all full-time employees, equality increases only marginally as the Atkinson index decreases from $9.19 \%$ to $9.14 \%$. This can be interpreted as the share of income that full-time employees would be willing to give up to achieve total wage income equality under the assumption that there are no other income sources available (Atkinson 1970). Even though the minimum wage raises inequality among the affected groups, its positive income effect on people who remain employed is sufficiently large to reduce overall income inequality.

\subsection{Fiscal effects}

There are several effects on the government budget. On the one hand, increasing wage income raises taxes and social security contributions. Furthermore, as far as affected employees are entitled to supplementary UB II payments, these payments will be reduced. These two effects increase fiscal revenues. On the other hand, the lay-offs of employees will lower tax revenues and social security contributions and will raise expenditures for unemployment benefit payments. For our calculations, we assume that all full-time and part-time employees who are laid off will receive UB I. If they received supplementary UB II even before becoming unemployed, they will receive the full UB II amount without any deductions. Persons formerly employed in a minijob who received supplementary UB II will continue to receive UB II; all other workers will not receive any public transfers when becoming unemployed. The respective shares of those employees receiving supplementary UB II are reported in column 3 of Table 3.2. Finally, we have to take into account that unemployment reduces gross output, which yields losses in tax revenues from other income sources. Since these incomes cannot be disentangled, we apply a uniform tax rate of $25 \%$.

Column 5 in Table 3.2 reports the total fiscal impact of a EUR 7.50 minimum wage. The additional fiscal costs outweigh the additional incomes of the affected households by far. In the aggregate, the additional public deficit amounts to more than EUR 4 billion per year. The highest fiscal burdens stem from the impact of the statutory minimum wage on full-time workers and on minijobs (see column 6).

An interesting measure can be obtained by dividing the additional household income by the fiscal cost the minimum wage has for each target group. The "implicit net transfer rate", reported in column 7, indicates the share of public spending that ends up in higher household incomes of the respective target groups. The lower the share, the more costly it is to finance redistribution via a minimum wage in a system that already provides basic income support to 
employees in the low-wage sector by supplementary UB II payments on low income. For persons with a minijob, the increase of private net income is a mere 9 cent of every additional euro spent by the government. For full-time workers, it is $41.4 \%$. Recall, however, that in the aggregate additional public spending does not reach those in need, i.e. those receiving supplementary UB II.

The minimum wage thus fails on two accounts. Firstly, it does not manage to raise the income of those who are really in need and, secondly, it fails to relieve the public budget. Rather than saving public expenditures for supplementary UB II, our calculations indicate that trying to shift the burden of the wage bill onto firms would cost the government an additional EUR 4 billion per year - needed mainly to finance the minimum-wage induced unemployment.

\section{Alternative measures to avoid working poor: general wage subsidies}

One of the main aims of a minimum wage is to reduce in-work poverty when working fulltime. The last section demonstrated that a minimum wage is hardly an appropriate instrument to achieve this goal. The fiscal cost of increasing the wage income of those workers whose income is close to the border of being "at risk of poverty" is immense and the small income gain for those remaining in employment comes at the cost of throwing a large share of low paid employees below this brink.

Can the government do better? In this section, we analyze the effect of two alternative concepts of a general wage subsidy. Both are designed in a way that guarantees fiscal equivalence, i.e. they cost the government exactly the same as the introduction of a statutory minimum wage of EUR 7.50 per hour.

The first alternative is considered only as a pure thought experiment. The government subsidizes the gross wage such that the fiscal costs are exactly the same for each wage bracket as in the case of a minimum wage. Of course, this implies that the government can observe hourly wages. While this assumption might appear critical, one should be aware that this is always implicitly assumed when calculating the minimum wage effects because the government would not be able to enforce a minimum wage if it could not observe hourly wages. We start with the case where the whole incidence of the wage subsidy is on the employer, i.e. labor costs are reduced by the amount of the wage subsidy. Table 4.1 reports the effects and provides a comparison with the effects of introducing a minimum wage. 
Table 4.1: Minimum wage vs payroll subsidies when the incidence is on the employer

\begin{tabular}{|c|c|c|c|c|c|c|c|c|c|c|c|c|c|}
\hline \multirow[b]{2}{*}{$\begin{array}{l}\text { Wage } \\
\text { bracket }\end{array}$} & \multirow[b]{2}{*}{$\begin{array}{l}\text { Change } \\
\text { in public } \\
\text { revenue } \\
\text { (in mill. } \\
€ / a)\end{array}$} & \multicolumn{3}{|c|}{$\begin{array}{l}\text { Minimum wage } \\
\text { EUR 7.50 }\end{array}$} & \multicolumn{4}{|c|}{ Differentiated payroll wage subsidy } & \multicolumn{5}{|c|}{$\begin{array}{c}\text { Subsidization of employer social security } \\
\text { contribution rate }\end{array}$} \\
\hline & & $\begin{array}{c}\text { Employment } \\
\text { effect in \% } \\
\text { of status quo }\end{array}$ & $\begin{array}{l}\text { Employment } \\
\text { effect }\end{array}$ & $\begin{array}{c}\text { Change in } \\
\text { aggregate } \\
\text { household } \\
\text { income } \\
\text { (in mill. } \\
€ / a) \\
{[5]}\end{array}$ & $\begin{array}{l}\text { Subsidy } \\
\text { rate }\end{array}$ & $\begin{array}{c}\text { Employment } \\
\text { effect in } \% \\
\text { of status quo }\end{array}$ & $\begin{array}{l}\text { Employment } \\
\text { effect } \\
\text { relative to } \\
\text { status quo }\end{array}$ & $\begin{array}{c}\text { Change in } \\
\text { aggregate } \\
\text { household } \\
\text { income } \\
\text { relative to } \\
\text { status quo } \\
\text { (in mill. } \\
€ / a) \\
{[9]}\end{array}$ & $\begin{array}{c}\text { Full } \\
\text { subsidization } \\
\text { below }\end{array}$ & $\begin{array}{l}\text { Average } \\
\text { wage } \\
\text { subsidy } \\
\text { rate }\end{array}$ & $\begin{array}{c}\text { Employment } \\
\text { effect in \% } \\
\text { of status quo }\end{array}$ & $\begin{array}{c}\text { Employment } \\
\text { effect } \\
\text { relative to } \\
\text { status quo }\end{array}$ & $\begin{array}{l}\text { Income } \\
\text { gain } \\
\text { relative to } \\
\text { status quo } \\
\text { (in mill } \\
€ / a) \\
{[14]}\end{array}$ \\
\hline$<3.00$ & $-1,158$ & $-49.9 \%$ & $-310,689$ & 179 & $39.8 \%$ & $46.3 \%$ & 288,147 & 1,500 & 6.83 & $15.0 \%$ & $13.0 \%$ & 80,793 & 420 \\
\hline $3.00-3.49$ & -225 & $-44.3 \%$ & $-56,708$ & 90 & $49.1 \%$ & $65.9 \%$ & 84,424 & 337 & 6.83 & $15.0 \%$ & $13.4 \%$ & 17,134 & 68 \\
\hline $3.50-3.99$ & -177 & $-37.7 \%$ & $-44,249$ & 57 & $40.8 \%$ & $48.2 \%$ & 56,659 & 267 & 6.83 & $15.3 \%$ & $13.3 \%$ & 15,595 & 73 \\
\hline $4.00-4.49$ & -157 & $-34.3 \%$ & $-60,163$ & 76 & $30.2 \%$ & $30.9 \%$ & 54,255 & 182 & 6.83 & $15.1 \%$ & $13.1 \%$ & 22,920 & 77 \\
\hline $4.50-4.99$ & -421 & $-25.4 \%$ & $-113,851$ & 118 & $25.7 \%$ & $24.9 \%$ & 111,682 & 564 & 6.83 & $15.3 \%$ & $13.2 \%$ & 59,298 & 298 \\
\hline $5.00-5.49$ & -413 & $-20.4 \%$ & $-74,926$ & 137 & $30.0 \%$ & $30.6 \%$ & 112,320 & 613 & 6.83 & $15.3 \%$ & $13.3 \%$ & 48,806 & 263 \\
\hline $5.50-5.99$ & -524 & $-15.5 \%$ & $-64,372$ & 168 & $27.9 \%$ & $27.8 \%$ & 114,978 & 584 & 6.83 & $15.6 \%$ & $13.6 \%$ & 56,340 & 287 \\
\hline $6.00-6.49$ & -416 & $-12.2 \%$ & $-67,828$ & 154 & $19.8 \%$ & $18.0 \%$ & 100,415 & 531 & 6.83 & $15.5 \%$ & $13.5 \%$ & 75,139 & 398 \\
\hline $6.50-6.99$ & -353 & $-4.5 \%$ & $-32,670$ & 98 & $11.1 \%$ & $9.2 \%$ & 66,410 & 317 & 6.83 & $15.6 \%$ & $13.5 \%$ & 97,248 & 466 \\
\hline $7.00-7.49$ & -166 & $-2.5 \%$ & $-16,577$ & 78 & $5.8 \%$ & $4.6 \%$ & 30,208 & 139 & 6.83 & $13.8 \%$ & $11.8 \%$ & 77,764 & 358 \\
\hline $7.50-7.99$ & & & & & & & & & 6.83 & $11.4 \%$ & $9.5 \%$ & 81,062 & 360 \\
\hline $8.00-8.49$ & & & & & & & & & 6.83 & $9.1 \%$ & $7.4 \%$ & 85,054 & 401 \\
\hline $8.50-8.99$ & & & & & & & & & 6.83 & $7.0 \%$ & $5.6 \%$ & 37,823 & 199 \\
\hline $9.00-9.49$ & & & & & & & & & 6.83 & $4.7 \%$ & $3.7 \%$ & 28,804 & 146 \\
\hline $9.50-9.99$ & & & & & & & & & 6.83 & $2.3 \%$ & $1.8 \%$ & 18,135 & 94 \\
\hline total & $-4,011$ & $-2.6 \%$ & $-842,033$ & 1,156 & & $3.1 \%$ & $1,019,498$ & 5,035 & & & $2.4 \%$ & 801,914 & 3,908 \\
\hline
\end{tabular}

Source: own calculations. 
The subsidy is non-monotonic with a peak slightly above EUR 3, for which wages are subsidized at a rate of $49.1 \%$. Higher wages would be subsidized at lower rates, reflecting the fact that both the adverse employment effects and the resulting fiscal cost decline when the initial wage becomes larger. Since the whole subsidy falls on the employer, labor cost declines and labor demand increases. In total, labor demand would increase by about 1 million compared to the status quo - this adds up to a plus of 1.8 million jobs compared to the minimum wage regime.

The wage subsidy also substantially increases aggregate household income. Those who are already in employment would not benefit at all since they would receive the same net income as before - irrespectively of whether they were eligible for UB II or not. As employment rises, however, all unemployed workers who now find employment realize a substantial gain in net income. To illustrate this, consider a re-employed worker who receives a gross wage of EUR 5 per hour, leading to a monthly gross wage income of EUR 800. If he did receive UB I, he would increase his income by EUR 258 per month (from EUR 386 to EUR 644). A new employee who is eligible for UB II would increase his income by EUR 240. Since the government saves on UB I and II and receives additional taxes and social security contributions, the gross amount that can be spent on the wage subsidy is much larger than the deficit of introducing the minimum wage regime. In total, the available income of all households that would be affected by a minimum wage would increase by EUR 3.9 billion per year relative to the income they received in the minimum wage regime. Furthermore, the income would be far more equally distributed within each wage bracket.

The second subsidy scheme considers a more realistic scenario. The government introduces an exemption limit below which the employers are fully exempted from social security contributions. ${ }^{10} \mathrm{Up}$ to $150 \%$ of the exemption limit, the employer contribution rates will be linearly increased until they reach the regular level of $19.5 \%$ of the gross wage. The exemption limit will be determined endogenously to ensure that the fiscal cost of this policy equals the cost of the minimum wage regime. We find that, compared to a statutory minimum wage of EUR 7.50, the exemption limit would have to be EUR 6.83 per hour. The wage subsidy rate $s$-formula thus becomes:

10 The analyzed proposal is in the spirit of an employer wage subsidy scheme the "Magdeburg Alternative" proposed by Schöb and Weimann (2006a), but abstracts away from institutional details of implementation. For a survey and a theoretical analysis, see Knabe, Schöb and Weimann (2006). 


$$
s=\left\{\begin{array}{ccc}
\frac{S S C}{1+S S C} & \text { for } & w \leq 6.83 € \\
\frac{S S C}{1+S S C}-\frac{S S C}{(1+S S C) \cdot 3.415}(w-6.83) & \text { for } \quad 6.83 €<w<10.245 € \\
0 & \text { for } \quad w \geq 10.245 €
\end{array}\right.
$$

Since we have different employer social security contribution rates (SSC) for full-time and part-time jobs on the one hand and minijobs on the other hand, the average effective wage subsidy rates do not decrease linearly with the wage rate because of the different composition of employment types within each wage bracket (see column [11] in Table 4.1).

The employment effects are smaller than in the case of differentiated wage subsidies but remain substantial. Total employment would rise by approximately $2.5 \%$ of the total workforce and by about 1.6 million workers compared to the employment level in the minimum wage regime. Because of the lower positive employment effect, the resulting income effect is also smaller. Nevertheless, aggregate household income rises by EUR 2.8 billion per year compared to the minimum wage regime.

The two scenarios summarized in Table 4.1 assume that the whole incidence falls on the employer, which guarantees a maximum employment effect. If the incidence falls partly on employees, the net incomes of incumbent workers would increase while the aggregate income effect of re-employment becomes smaller. Table 4.2 reports the effect we would obtain for the two scenarios - differentiated wage subsidy and the exemption-limit-with-phase-out subsidy regime - when the whole incidence falls on the employees. ${ }^{11}$ The employment effect would be identically zero as we assume that the labor demand side is the short side of the labor market. Thus, the employment effect compared to the minimum wage regime is 842,000 jobs. The income effect is now twofold. Incumbent workers would face a huge increase in the net income when they do not depend on supplementary UB II. By contrast, most UB II recipients would not benefit at all since the constant gross wage income determines the allowance they can keep - irrespectively of the resulting net wage income. However, the critical income level above which no supplementary UB II is paid falls.

\footnotetext{
11 This is done by assuming that the wage subsidy is directly given to the employees by reducing their social security contributions, keeping the gross wage constant.
} 
Table 4.2: Minimum wage vs payroll subsidies: pure increase in net wage incomes

\begin{tabular}{|c|c|c|c|c|c|}
\hline & \multicolumn{2}{|c|}{$\begin{array}{c}\text { Differentiated payroll wage } \\
\text { subsidy }\end{array}$} & \multicolumn{3}{|c|}{$\begin{array}{l}\text { Subsidization of employer social } \\
\text { security contribution rate }\end{array}$} \\
\hline $\begin{array}{l}\text { Wage } \\
\text { bracket }\end{array}$ & $\begin{array}{c}\text { Subsidy } \\
\text { rate (on gross } \\
\text { wages) }\end{array}$ & $\begin{array}{c}\text { Income } \\
\text { gain relative } \\
\text { to status } \\
\text { quo } \\
\text { (in mill. } \\
€ / a) \\
{[6]}\end{array}$ & $\begin{array}{c}\text { Full } \\
\text { subsidization } \\
\text { below } \\
\\
{[7]}\end{array}$ & $\begin{array}{l}\text { Average } \\
\text { wage } \\
\text { subsidy } \\
\text { rate (on } \\
\text { gross } \\
\text { wages) } \\
{[8]}\end{array}$ & $\begin{array}{c}\text { Income } \\
\text { gain } \\
\text { relative } \\
\text { to status } \\
\text { quo } \\
\text { (in mill. } \\
€ / a \text { ) } \\
{[9]}\end{array}$ \\
\hline$<3.00$ & $53.4 \%$ & 1,158 & 5.65 & $19.5 \%$ & 422 \\
\hline $3.00-3.49$ & $52.2 \%$ & 225 & 5.65 & $19.5 \%$ & 84 \\
\hline $3.50-3.99$ & $44.5 \%$ & 177 & 5.65 & $19.5 \%$ & 77 \\
\hline $4.00-4.49$ & $30.1 \%$ & 157 & 5.65 & $19.5 \%$ & 102 \\
\hline $4.50-4.99$ & $25.6 \%$ & 421 & 5.65 & $19.5 \%$ & 320 \\
\hline $5.00-5.49$ & $25.7 \%$ & 413 & 5.65 & $19.5 \%$ & 312 \\
\hline $5.50-5.99$ & $19.1 \%$ & 524 & 5.65 & $18.7 \%$ & 513 \\
\hline $6.00-6.49$ & $13.4 \%$ & 416 & 5.65 & $15.3 \%$ & 476 \\
\hline $6.50-6.99$ & $6.5 \%$ & 353 & 5.65 & $11.8 \%$ & 649 \\
\hline $7.00-7.49$ & $2.6 \%$ & 166 & 5.65 & $8.4 \%$ & 530 \\
\hline $7.50-7.99$ & --- & --- & 5.65 & $4.9 \%$ & 351 \\
\hline $8.00-8.49$ & --- & --- & 5.65 & $1.5 \%$ & 176 \\
\hline total & --- & 4,011 & --- & --- & 4,011 \\
\hline
\end{tabular}

Source: own calculations.

Figure 4.1 shows how employment and income of the affected households vary depending on the incidence of the wage subsidy. The larger the incidence falls on employees, the smaller is the employment effect because of the lower impact the wage subsidy has on labor cost. By contrast, the aggregate additional household income is relatively stable at about EUR 4 billion per year, with a maximum of EUR 4.05 billion and a minimum of EUR 3.91 billion per year. 
Figure 4.1: Employment and income depending on subsidy incidence

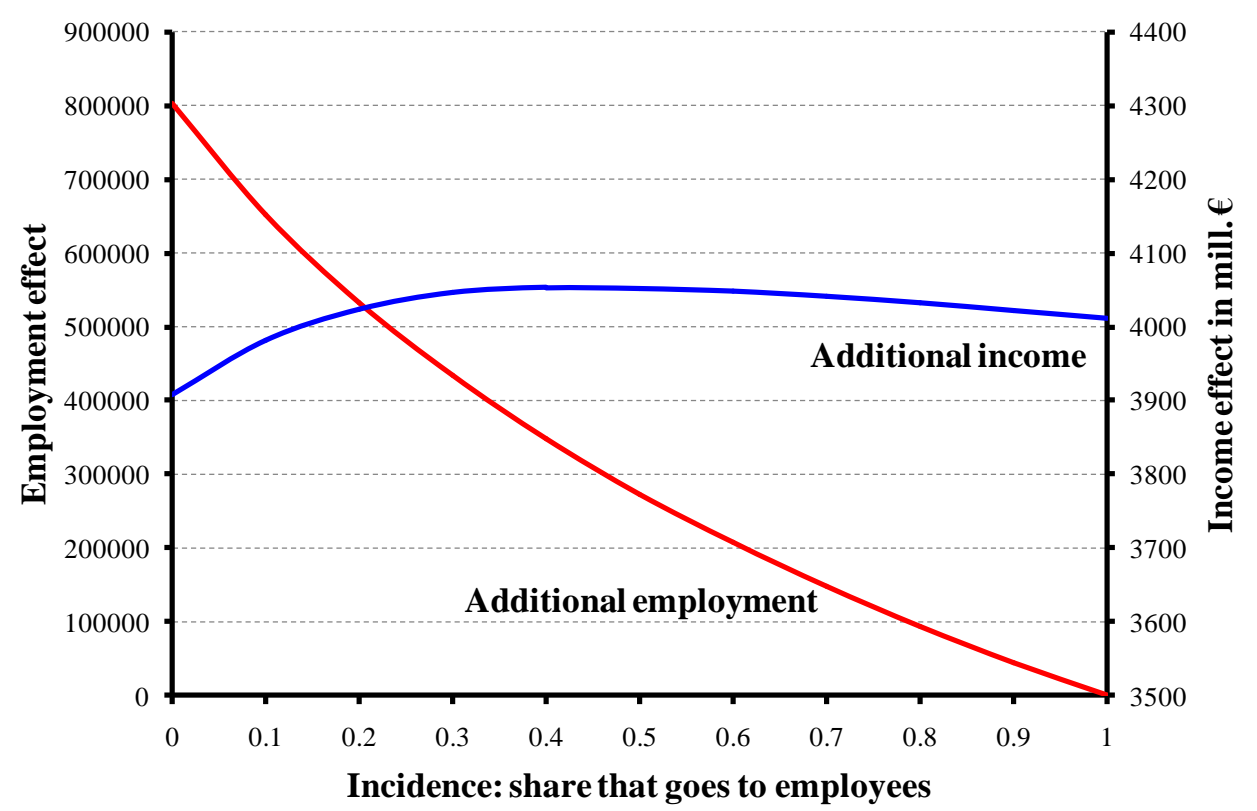

Source: own calculations

Independently of whether the employers receive the subsidy or whether it is passed on onto employees, the subsidization of social security contributions in the low-wage sector reduces income inequality. If the incidence is entirely on employers, incomes of incumbent workers do not change, but some formerly unemployed persons get a job. Since wages in the lowwage sector hardly exceed the level of unemployment benefits of short-term unemployed ${ }^{12}$ or, in the case of UB II recipients, are subject to high benefit reduction rates, the incomes of the new employees do not rise very much. Even though about 800,000 new jobs are created, the Atkinson inequality index falls by only 0.03 percentage points. This effect on income inequality is of a similar magnitude as that of the minimum wage. If one aims at reducing income inequality, subsidies on employees appear to be a more effective policy. If the subsidy on social security contributions is shifted to employees, employment stays constant, but incumbent employees benefit from a substantial rise in wages. The Atkinson inequality index then falls by 0.27 percentage points. This shows that income inequality can best be reduced if the government gives subsidies directly to the needy instead of trying to shift the burden onto firms by setting minimum wages.

\footnotetext{
12 We assume that all new employees who do not receive supplementary UB II earn the same wage as in their previous job. These workers are recruited from the pool of short-term unemployed so that they were eligible for Unemployment Benefits I before becoming reemployed.
} 


\section{Neutralizing the minimum wage}

The minimum wage aims at securing higher incomes in the low wage sector. We have seen so far that the minimum wage fails to do this when it is implemented in an already existing system of basic income support. It may nevertheless serve as a redistributive tool if one can avoid the negative employment effects, for instance, by implementing a complementary wage subsidy. We will call such a combination of a minimum wage and a wage subsidy the "French approach". In France, the minimum wage is accompanied by a subsidy of the employers' social security contributions, which is equal to 26 percentage points at the minimum wage level and is linearly melted down to the 1.6 -fold of the minimum wage. ${ }^{13}$

To see how these two instruments interact, consider a stylized model of the labor market, which is characterized by a decreasing labor demand $L(w)$ and a fixed labor supply $N$. The wage the employer pays to its employees is $w$, i.e. we abstract from all taxes and social security contributions. Full employment $L=N$ could be achieved by a wage rate equal to $w_{0}$. Figure 5.1 illustrates this outcome. If the equilibrium wage falls below a subsistence income $b$, which the government would like to guarantee each worker, the government may set a minimum wage equal to $w^{\min }=b$. In this case, labor demand falls to $L_{0}$ and unemployment equals $N-L_{0}$. Section 3 estimated this negative employment effect.

Full employment can be sustained when the government steps in and fills the gap between the wage $w_{0}$ and $b$ by introducing a general wage subsidy $s$. In the presence of a statutory minimum wage, the wage subsidy has to be paid directly to the employer to induce any employment effect. In this case, labor demand becomes $L(w-s)$ and shifts upwards by the amount $s$, thereby increasing labor demand. Employers' effective labor costs are reduced to their market-clearing level $w_{0}$. If set appropriately, as shown in Figure 5.1, full employment can be reached. The guaranteed subsistence income $b$ is equal to the wage rate $w$ the employee obtains while the gross labor cost are lower by the amount $s$.

\footnotetext{
13 See Kramarz and Philippon (2001) and Laroque and Salanié (2002) for details and empirical evidence. They disentangle the employment effects from the minimum wage from those induced by the wage subsidy scheme.
} 
Figure 5.1: Statutory minimum wage and a general wage subsidy

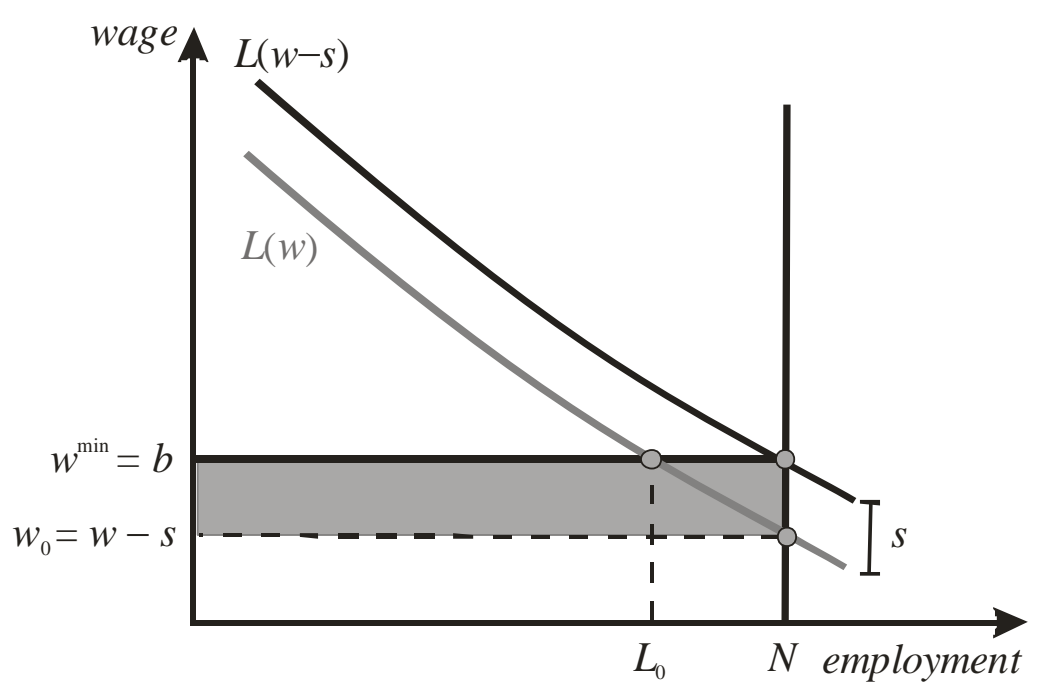

Such a combination of minimum wage and wage subsidy to employer is allocatively equivalent to a wage subsidy to employees when labor markets are flexible, and thus leads to the same income distribution. The only difference is the fact that with the minimum wage the employee receives his income from one source only, whereas with the wage supplement he receives his income from two sources (see Schöb and Weimann 2006b). In functioning markets, one of the fundamental results of the theory of taxation applies, namely, that it does not make any difference which side of the market - employee or employer - has to pay the tax or receives the subsidy. In both cases, the incidence falls on the employer. A statutory minimum wage destroys this equivalence result but still allows us to reach an efficient outcome. It is only the choice set of complementary instruments that is limited by a statutory minimum wage, not efficiency itself. The minimum wage alone thus cannot be held responsible for unemployment. It is the too large demand on the redistributive system which is not accommodated by appropriate policy measures that does the harm. Hence, in theory, a minimum wage can be introduced in an employment-neutral way. So far for the theory! But how would it work in real life?

In the following, we analyze how the French approach would work in Germany. We examine a wage subsidy, which is introduced to completely neutralize the adverse effects of an isolated introduction of a statutory minimum wage as shown in Section 3. We therefore calculate a maximum subsidy rate that is paid for workers who receive the minimum wage. Similar to the French system, the subsidy is then linearly decreased and fades out at $150 \%$ of the minimum wage rate. By neutralizing the employment effect, we mean that the full-time 
equivalent status quo employment level is kept constant when the minimum wage in combination with the wage subsidy scheme is introduced. The endogenously determined maximum subsidy is $21.2 \%$ for a minimum wage of EUR 5.00. This is equal to 1.06 cent per hour. The interval in which wages are subsidized is between EUR 5.00 and EUR 7.50. For a minimum wage of EUR 7.50, the maximum subsidy is $18.5 \%$, or EUR 1.39 per hour. The subsidy phases out at a wage of EUR 11.25.

In Table 5.1, we report the main findings for the combined reform scenario. A moderate statutory minimum wage of EUR 5.00 can be neutralized by a wage subsidy at a total fiscal cost of EUR 2.5 billion per year. The additional aggregate household income is almost EUR 1.6 billion per year compared to a mere EUR 222 million when only the statutory minimum wage is introduced. This is due to the fact that the wage subsidy eliminates the adverse employment effects (in the aggregate). Since the fiscal cost of an isolated minimum wage is already about EUR 900 million per year, the pure gross cost of neutralizing the adverse employment effect is only EUR 1.6 billion per year. If we deduct the differential income effect, the net cost of neutralization is even smaller (EUR 231 million).

The net cost of neutralization rises if the minimum wage is higher. For a statutory minimum wage of EUR 7.50, the net cost of neutralization sums up to EUR 7.6 billion per year with gross cost being EUR 11.5 billion per year. This clearly indicates the inefficacy of combined introduction of a high statutory minimum wage with neutralizing wage subsidies. The French model is - if at all - only suitable for moderate statutory minimum wages. ${ }^{14}$ Even very moderate statutory minimum wages, however, could open Pandora's box. Once introduced, there would be nothing that prevents politicians from demanding ever higher minimum wage levels (see Franz et al., 2008).

\footnotetext{
${ }^{14}$ Rürup (2008) is the most prominent economist in favor of moderate statutory minimum wages. He considers them as an appropriate complementary measure to wage subsidies to employees that avoids that firms take advantage of wages subsidies and lower gross wages.
} 
Table 5.1: Minimum wage and neutralizing wage subsidies

\begin{tabular}{c|c|c|c|c|c}
\hline \hline $\begin{array}{c}\text { Statutory } \\
\text { minimum } \\
\text { wage }\end{array}$ & $\begin{array}{c}\text { Wage } \\
\text { subsidy at } \\
\text { minimum } \\
\text { wage level }\end{array}$ & $\begin{array}{c}\text { Additional } \\
\text { household } \\
\text { income } \\
\text { relative to } \\
\text { status quo in } \\
\text { mill. euro/a }\end{array}$ & $\begin{array}{c}\text { Fiscal cost in } \\
\text { mill. euro/a }\end{array}$ & $\begin{array}{c}\text { Gross cost of } \\
\text { neutralization } \\
\text { in mill. euro/a }\end{array}$ & $\begin{array}{c}\text { Net cost of } \\
\text { neutralization } \\
\text { in mill. euro/a }\end{array}$ \\
\hline \hline 5.00 & $21.2 \%$ & 1,561 & 2,491 & 1,570 & 231 \\
6.00 & $19.5 \%$ & 2,647 & 5,921 & 4,224 & 2,056 \\
7.50 & $18.5 \%$ & 5,068 & 15,562 & 11,552 & 7,639
\end{tabular}

Source: own calculations.

Note: Gross costs of neutralization are given by the difference between the fiscal cost of neutralization and the fiscal cost of introducing the minimum wage without complementary measures. The net costs are obtained by subtracting the change in household income relative to the case with a non-neutralized minimum wage.

Table 5.2 shows how the different groups are affected. Because we have neutralized the adverse employment effect with respect to full-time equivalent employment, the actual employment figures may be different. To see how the combined measure affects households with an initial hourly wage income below and above the statutory minimum wage, we present the data separately. As expected, the wage subsidy can only partly redo the increase in labor cost below EUR 7.50 but it actually lowers labor cost in the range from EUR 7.50 to EUR 11.25. In total, the number of jobs falls by almost 3,000 because, by keeping the number of full-time equivalent jobs constant, more minijobs are lost than full-time jobs are created. The group of persons working in a minijob is the group that loses most jobs.

Table 5.2: Employment effects among different target groups

\begin{tabular}{|c|c|c|c|c|c|}
\hline Initial wage & $\begin{array}{c}\begin{array}{c}\text { All } \\
\text { employees }\end{array} \\
\text { UB II } \\
\end{array}$ & $\begin{array}{r}\begin{array}{c}\text { Full-time } \\
\text { employees }\end{array} \\
\text { UB II }\end{array}$ & $\begin{array}{r}\begin{array}{r}\text { Part-time } \\
\text { employees }\end{array} \\
\text { UB II }\end{array}$ & $\begin{array}{l}\text { Minijobs } \\
\text { UB II }\end{array}$ & $\begin{array}{l}\text { Pensioners \& } \\
\text { students }\end{array}$ \\
\hline$<$ EUR 7.50 & $\begin{array}{r}-398,615 \\
-94,907\end{array}$ & $\begin{array}{r}-33,470 \\
-2,708\end{array}$ & 4,068 & $\begin{array}{r}-320,178 \\
-91,880\end{array}$ & $-49,035$ \\
\hline >EUR 7.50 & $\begin{array}{r}395,810 \\
16,616\end{array}$ & \begin{tabular}{|r|}
203,703 \\
7,939 \\
\end{tabular} & $\begin{array}{r}54,143 \\
4,465\end{array}$ & $\begin{array}{r}103,862 \\
4,213\end{array}$ & 34,103 \\
\hline Total effects & $\begin{array}{r}-2,805 \\
-78,291\end{array}$ & \begin{tabular}{|r|}
170,233 \\
5,230
\end{tabular} & \begin{tabular}{|r|}
58,211 \\
\\
4,146
\end{tabular} & \begin{tabular}{|r|}
$-216,316$ \\
$-87,667$
\end{tabular} & $-14,933$ \\
\hline
\end{tabular}

Source: own calculations.

Interestingly, the reform hardly affects full-time and part-time employees who are eligible for supplementary UB II. However, UB II recipients who have a low-paid minijob are the ones 
who suffer most from the reform. In total, more than 78,000 UB II recipients lose their jobs while 75,000 additional jobs are created for those who are not in need. The resulting income effects for the different groups are shown in Table 5.3.

Table 5.3: Income effects among different target groups (in mill. Euro per year)

\begin{tabular}{|c|c|c|c|c|c|}
\hline Initial wage & $\begin{array}{r}\text { All } \\
\text { employees } \\
\text { UB II }\end{array}$ & $\begin{array}{r}\text { Full-time } \\
\text { empoyees } \\
\text { UB II }\end{array}$ & $\begin{array}{r}\text { Part-time } \\
\text { employees } \\
\text { UB II }\end{array}$ & $\begin{array}{r}\text { Minijobs } \\
\text { UB II }\end{array}$ & $\begin{array}{c}\text { Pensioners \& } \\
\text { students }\end{array}$ \\
\hline$<$ EUR 7.50 & 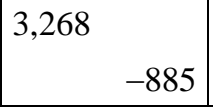 & -27 & -3 & $\begin{array}{ll}1,205 & \\
& -855\end{array}$ & 299 \\
\hline >EUR 7.50 & 1,800 & 1,051 & 188 & 433 & 128 \\
\hline Total effect & $\begin{array}{rr}5,068 & \\
& -700\end{array}$ & 2,538 & 44 & $\begin{array}{rr}1,639 & \\
& -816\end{array}$ & 427 \\
\hline
\end{tabular}

Source: own calculations.

The total income gain for the affected households is EUR 5 billion per year. Half of the gain accrues to full-time employees, the second largest share goes to persons with a minijob. Since the existing rules about supplementary UB II ensure that the potential gains from a minimum wage for UB II recipients is small while the income loss when laid off is much higher, fulltime and part-time employees eligible for supplementary UB II hardly gain from this reform option. The only significant effect is that less productive workers lose while those with higher productivity, ensuring a wage above the minimum wage, will benefit. UB II recipients who hold a low-paid minijob are the great losers with an annual loss of more than EUR 800 million. In total, the income of UB II recipients will fall so that even a minimum wage with accompanying employment-neutralizing measures fails to increase income of the most important target group, i.e. the households in need. Income inequality in the lowest wage brackets increases (the Atkinson index for wage brackets below EUR 7.50 increases by 0.65 percentage points). The Atkinson index for all full-time employees falls by 0.20 percentage points. Thus, overall income inequality is reduced more than under a pure minimum wage, but less than for the (considerably cheaper) subsidy to employees. A neutralized minimum wage is thus not only extremely costly, it also does not serve the objectives minimum wage supporters pursue. 


\section{Discussion}

According to the $3^{\text {rd }}$ German government report on poverty and wealth, issued in 2008, approximately 13 percent of the German population was supposed to be at risk of poverty in 2005. There are two main reasons for this individual risk of poverty constantly referred to: low educational attainment and unemployment. 'In-work poverty' is not mentioned and for good reasons. Since every citizen in Germany is entitled to a basic income support when in need and after having exhausted all other available options, the German social system today still prevents those who are in employment to drift off into poverty. A minimum wage is thus not needed to fight poverty.

If, however, one nevertheless wants to raise the incomes and employment chances of the 'working poor', we argue in this paper that the minimum wage appears to be an ill-designed policy. We have compared the effects of minimum wages to alternative policies that also aim to increase the incomes and employment prospects of low-wage workers. Table 6.1 summarizes our findings. A minimum wage of EUR 7.50 per hour turns out to have only a small positive effect on aggregate incomes of the affected households, but causes enormous job losses. Since higher wages for some workers come at the cost of job and income losses for others, inequality among the low-paid increases. Overall income inequality is only slightly reduced. The adverse effects of the minimum wage are even stronger for those most in need. Poor households receive means-tested welfare benefits (UB II). Since higher wages are deducted from welfare benefits at rates between $90 \%$ and $100 \%$ in the relevant income interval, a minimum wage can only have a very small impact on net incomes of those in need. Even worse, since the minimum wage dramatically raises labor cost while only moderately increasing net incomes, our calculations show that the income losses of those people who lose their jobs exceed the income gains of those remaining in employment. The minimum wage makes the groups most in need worse off.

The same considerations also refute the argument that a statutory minimum wage will reduce public expenditures. While a minimum wage would succeed in decreasing the supplementary UB II payments for the employed workers, it would force the government to spend more funds on additional unemployment benefits. The additional expenditures on unemployment benefits outweigh the savings in transfers to those still employed by about EUR 4 billion a year. 
One may be inclined to argue in favor of introducing a minimum wage as a redistributive tool if it is supplemented with a complementary wage subsidy that neutralizes the adverse employment effects. Such a subsidy has been implemented, for example, in France to compensate employers for higher minimum wages. This 'French approach', however, does not seem to be a suitable policy measure for Germany. At a statutory minimum wage of EUR 7.50, public spending would be up by EUR 15.6 billion a year while only generating EUR 5.1 billion additional income per year for the affected households. The attempt to neutralize the adverse employment effect of minimum wages by paying wage subsidies to employers turns out to create windfall gains to employers and employees who are not in need and earn an hourly wage above the minimum wage.

Table 6.1: Summary: changes relative to status quo

\begin{tabular}{l|cccc}
\hline \hline & $\begin{array}{c}\text { Additional } \\
\text { household } \\
\text { Change in } \\
\text { income in } \\
\text { mill. EUR } \\
\text { p.a. }\end{array}$ & $\begin{array}{c}\text { Fiscal cost in } \\
\text { mill. EUR } \\
\text { p.a. }\end{array}$ & $\begin{array}{c}\text { Change in } \\
\text { Atkinson } \\
\text { inequality } \\
\text { index }\end{array}$ \\
\hline $\begin{array}{l}\text { minimum wage of EUR 7.50 } \\
\begin{array}{l}\text { linear wage subsidy (incidence } \\
\text { on employers) }\end{array}\end{array} \quad-842,033$ & 1,156 & $-4,011$ & $-0.05 \%$ \\
$\begin{array}{l}\text { linear wage subsidy (incidence } \\
\text { on employees) }\end{array}$ & 0 & 3,908 & $-4,011$ & $-0.03 \%$ \\
$\begin{array}{l}\text { minimum wage of EUR 7.50 } \\
\text { plus linear wage subsidy } \\
\text { (incidence on employers) }\end{array}$ & $-2,805$ & 5,068 & $-15,014$ & $-0.27 \%$ \\
\hline \hline
\end{tabular}

Source: own calculations.

As the 2008 German government report on poverty and wealth pointed out, the most promising policy to fight poverty, apart from long-term measures such as improving the educational system, is to create new employment possibilities for low-productive workers. This can be achieved by policies that reduce labor cost in the low-wage segment of the labor market. In our paper, we analyzed a wage subsidy scheme that reduces the social security contribution rate for low income groups.

Whether the incidence of such a subsidy is on employers or employees is, in the long run, entirely determined by labor demand and labor supply. Market forces will lead to identical equilibrium outcomes in both cases (see e.g. Borjas 2000, p. 170). The short-run adjustment 
period, however, matters. While subsidies given to employers lower labor cost immediately, wage subsidies given to employees only work after they are transformed into lower gross wages which can take a considerable amount of time. These differences in the timing are often disregarded in economists' policy advice on labor market issues. As Blinder (1988, p. 12) puts it:

"The difference between the long-run equilibrium results that we know and love (and teach to our young) and the short-run disequilibrium results that people actually experience are no mere quibbles. They may be fundamental." 15

As we do not know how long the short run is, a reduction of employers' social contribution rate is more favorable than the reduction of the employees' social security contribution rate, guaranteeing additional medium run employment gains. Furthermore, if market forces are impaired, even the long-run incidence may be different. This could happen if, for example, labor unions can protect the interest of insiders, i.e. the interest of incumbent workers.

Our calculations show that, if the incidence of such a subsidy falls completely on the employer, a wage subsidy that is as costly as a statutory minimum wage of EUR 7.50 would allow the creation of around 800,000 new jobs and raise the income of the affected households by almost EUR 4 billion per year. If the incidence falls completely on the employee, we would have no positive employment effects but income effects of similar magnitude. The additional income would, however, accrue only to incumbent workers.

Whatever is the precise policy objective, the results in Table 6.1 clarify that a minimum wage is an inferior policy to wage subsidies. If the government is willing to spend the same amount of money directly on wage subsidies that it would otherwise have to spend indirectly to finance the cost of minimum wages through higher expenditures on unemployment and welfare benefits, it could achieve more favorable employment and income effects with wage subsidies than with minimum wages. Hence, the responsibilities of the welfare state to ensure sufficient incomes and employment prospects also at the lower end of the income distribution can be achieved more efficiently if the government abandons plans to install minimum wages and instead focuses on a policy to subsidize low-paid jobs directly.

\footnotetext{
${ }^{15}$ Hamermesh (1980), using an empirically founded simulation for the United States, shows that the half-life of the adjustment process after a change in the payroll tax is about five years. We expect the half-life to be even longer in unionized labor markets with insider power.
} 


\section{References}

Atkinson, A. (1970): "On the measurement of inequality", Journal of Economic Theory 2, 244-263.

Bachmann, R., Th. Bauer, J. Kluve, S. Schaffner, and Ch. Schmidt (2008): Mindestlöhne in Deutschland. Beschäftigungswirkung und fiskalische Effekte, RWI Materialien 43, Essen.

Blinder, A. (1988): "The Challenge of High Unemployment", American Economic Review 78, $1-15$.

Borjas, G. (2000): Labor Economics, $2^{\text {nd }}$ ed., McGraw-Hill, Boston.

Brenke, K. (2007): "Zunehmende Lohnspreizung in Deutschland", DIW-Wochenbericht 74, 73-79.

Brenke, K., and J. Ziemendorff (2008): „Hilfebedürftig trotz Arbeit? - kein Massenphänomen in Deutschland“, DIW Wochenbericht 75(4), 33-40.

Bundesbank (2008): Monatsbericht September 2008, Frankfurt.

Bundesministerium für Arbeit und Soziales (2008a): Lebenslagen in Deutschland. der 3. Armuts- und Reichtumsbericht der Bundesregierung, Entwurf vom 19. Mai 2008, Berlin.

Bundesministerium für Arbeit und Soziales (2008b): Die 10 wichtigsten Fragen und Antworten zum Mindestlohn, http://194.145.122.101/sites/generator/25932/property=pdf/faq.pdf

Brown, C. (1999): "Minimum Wages, Employment and the Distribution of Income", in O. Ashenfelter and D. Card (eds.) Handbook of Labor Economics, Vol. 3B Amsterdam, North Holland, 2101-2163.

Card, D., and A. B. Krueger (1995): Myth and measurement: the new economics of the minimum wage, Princeton University Press.

Dustmann, C., J. Lundstek,, and U. Schönberg (2008): "Revisiting the German Wage Structure", forthcoming in Quarterly Journal of Economics.

European Commission (2006): Portfolio of overarching indicators and streamlined Social Inclusion, Pensions, and Health portfolios, Employment, Social Affairs and Equal Opportunities DG - Social protection and social integration, Brussels.

Franz, W. (2007): "Ein zielgerichtetes Kombilohnmodell: Der Vorschlag des Sachverständigenrates“, ifo Schnelldienst 60 (4), 24-28.

Franz, W. B. Weder di Mauro, and W. Wiegard (2008): "Hände weg von Mindestlöhnen,“ Ifo Schnelldienst 61(6), 8-12.

Gernandt, J., and F. Pfeiffer (2007): "Rising Wage Inequality in Germany", Jahrbücher für Nationalökonomie und Statistik 227(4), 358-380.

Hamermesh, D. (1980): "Factor Market Dynamics and the Incidence of Taxes and Subsidies", Quarterly Journal of Economics 95, 751-764.

Kleinhenz, G., and S. Bauernschuster (2008): "Staatlicher Mindestlohn - Musterfall eines Mangels an Aufklärung über die Ökonomik sozialer Politik“, Ifo Schnelldienst 61(6), 4549.

Knabe, A., R. Schöb and J. Weimann (2006): "Marginal Employment Subsidization: A New Concept and a Reappraisal“", Kyklos 50(4), 557-578.

Kramarz F., and T. Philippon (2001): "The Impact of Differential Payroll Tax Subsidies on Minimum Wage Employment", Journal of Public Economics 82, 115-146.

König, M., and J. Möller (2007): Mindestlohneffekte des Entsendegesetzes? Eine Mikrodatenanalyse, IAB Discussion Paper No. 30, May.

Laroque, G. and B. Salanié (2002): "Labour Market Institutions and Employment in France“, Journal of Applied Econometrics 17, 25-48.

Meier, V., and S. Munz (2008): "Beschäftigungseffekte von Mindestlöhnen unter Vernachlässigung der Hauptbetroffenen: Kommentar zu König und Möller", ifo Schnelldienst 61(15), 30-32.

Müller, K.-U., and V. Steiner (2008a): "Mindestlöhne kosten Arbeitsplätze: Jobverluste vor allem bei Geringverdienern", DIW Wochenbericht Nr. 30, S. 418-423.

Müller, K.-U., and V. Steiner (2008b): Would a legal minimum wage reduce poverty? A microsimulation study for Germany, DIW Discussion Paper No. 791, May. 
Neumark, D., and W. Wascher (2000): “The Effect of New Jersey's Minimum Wage Increase on Fast-Food Employment: A Reevaluation Using Payroll Records", American Economic Review 90(5), 1362-96.

Neumark D., and W. Wascher (2007): Minimum Wages and Employment, IZA Discussion Paper No. 2570, January.

Prasad, E. (2004): "The unbearable stability of the German wage structure: evidence and interpretation", IMF Staff Papers 51(2), 354-385.

Projektgruppe Gemeinschaftsdiagnose (2008): Folgen der US-Immobilienkrise belasten Konjunktur, Gemeinschaftsdiagnose Frühjahr 2008, Essen.

Ragnitz, J., and M. Thum (2007): "The empirical relevance of minimum wages for the lowwage sector in Germany", CESifo Forum 2/2007, 35-37.

Rürup, B. (2008): "Für einen moderaten allgemeinen Mindestlohn", Ifo Schnelldienst 61(6), 5-7.

Sachverständigenrat zur Begutachtung der gesamtwirtschaftlichen Entwicklung (2006a) Arbeitslosengeld II reformieren: Ein zielgerichtetes Kombilohnmodell, Wiesbaden.

Sachverständigenrat zur Begutachtung der gesamtwirtschaftlichen Entwicklung (2006b): Widerstreitende Interessen - Ungenutzte Chancen, Jahresgutachten 2006/2007, Stuttgart: Metzler-Poeschler.

Schöb, R., and J. Weimann (2006a): Arbeit ist machbar - Die Magdeburger Alternative: Eine sanfte Therapie für Deutschland, Janos Stekovics Verlag: Dößel, 5th edition.

Schöb, R., and J. Weimann (2006b): "Kombilohn und Mindestlohn: Das kleine Steuerüberwälzungseinmaleins", Wirtschaftsdienst 86, 102-104.

Sinn, H.-W. et al. (2006a): "Aktivierende Sozialhilfe 2006: Das Kombilohn-Modell des ifo Instituts", ifo Schnelldienst 59(2), 6-27.

Sinn, H.-W. et al. (2006b): Redesigning the Welfare State. Germany's Current Agenda for an Activating Social Assistance, Edward Elgar: Cheltenham.

Sinn, H.-W. et al. (2007): "Die zentralen Elemente der Aktivierenden Sozialhilfe", ifo Schnelldienst 60 (4), 48-53.

Statistisches Bundesamt (2006): Fachreihe 1. R 4.2.1, 2. VJ/2006, Wiesbaden.

Statistisches Bundesamt (2007): Statistisches Jahrbuch 2006, Wiesbaden.

Wagner, G., J. Frick, and J. Schupp (2007): "The German Socio-Economic Panel Study (SOEP) - Scope Evolution and Enhancements", Schmollers Jahrbuch 127(1), 139-169. 